P-ISSN: 2301-9913, E-ISSN: 2597-9132

Globish (An English-Indonesian journal for English, Education and Culture

Vol. 8, No.2, July 2019,

P-ISSN: 2301-9913, E-ISSN: 2597-9132

DOI: http://dx.doi.org/10.31000/globish.v7i2

\title{
Navigating Gender and Patriotism in Captain America Trilogy Movie
}

\author{
${ }^{1}$ Cut Novita Srikandi, 2 Erlangga \\ English Education Study Program Teachers Training and Education \\ Faculty, Muhammadiyah University of Tangerang \\ Email: cutnovitasrikandi@umt.ac.id
}

\begin{abstract}
This articles revisits Michel Foucault and Judith Butler's work on the gender and sexuality by examining contemporary cultural spectacles of heterosexual men, exemplified in the movie Captain America Trilogy. We will re-evaluate the queerness based on Foucault's Sexual Discourse by thinking about the intersections between queer heroes and queer soldier. Result Show that struggle queer individuals endure with heteronormative standard culture forces them to change standard culture things and forms to create them applicable. Captain America shut relationship with Bucky provides for a queer reading and therefore the history of Captain America among the relative queer freedom caused by socio-historic conditions of war II find this queer reading during a larger queer history. And by claiming Steve Rogers and Bucky as their own queer people create space to express their identities and reaffirm the place of heroic queer people in American history which, as the descendants of that patriotic past, merits them a place within that history and within modern American society.
\end{abstract}

Keywords: Gender in American Society, queer heroes, gender identities

\section{INTRODUCTION}

Captain America is an icon of comic history in the United States and with the rise of Marvel Cinematic Universe, or MCU, his audience has only expanded since the character's debut in 1941. Today the character attracts large box workplace numbers; war, the foremost recent Captain America film, as of might seventeen, 2016 has made \$952 million dollars worldwide (Box Office Mojo, 2016). The dominant constructions of this character by Marvel, Disney, and fans 
have viewed and tried to gift Captain America as heterosexual; but, the character has found a community that reads him as a bisexual or gay man. Queer fans have actively seen Captain America this way because they don't always see themselves in popular culture and, in order to make these items and forms more relevant, they adapted them into queer readings. While the allied agents typically known as the ability alinement, will continue to deny a queer reading and actively encourage a straight reading in the canon, the relationship between Bucky Barnes and Captain America lends to a queer reading that is impo ssible to separate from the character. By seeing Captain America as queer, readers affirm their identities and place in trendy society and United States of America history.

Many folks took to defend a straight Captain America, as well as William Hicks from the Prince Rupert Murdoch's news web site HeatStreet. In a dissection of Robinson's argument Hicks (2016) wrote,"And then there's this life style piece, "Is This the One Flaw within the Otherwise nice Captain America: Civil War?" The one flaw is Cap's outright heterosexuality. Apparently Cap's love interest who takes up, at tops, five minutes of the movie was too much for the author".

This is an example of an allegiance between the cultural producers of Captain America and some fans to uphold a straight narrative and, while meant to be a critique, this statement details why the heteronormative inclusion is thus displeasing to Robinson. In fact, the news website vocalization even printed a tweet with the tagline "What was up thereupon weird Captain America: war kiss?" that links to their article on the film that argues this straight kiss between Steve and Sharon feels contrived.

In 2015, film producer featured no queer characters in any of the films it discharged and also the remainder of the key studios combined solely featured Received April 07, 2019 ; Revised April 20, 2019; Accepted Mei 7, 2019 

Forty seven queer characters, including small and side characters, in their 126 feature-length film releases (2016 GLAAD Studio Responsibility Index). By creating queer folks nearly nonexistent on screen queer readers square measure forced to "poach" an item of culture, a straight Captain America, and adapt it (make it queer) so it's relevant to them. Jenkins provides proof of a fallible model to counter this "poaching" that individuals aligned with the dominant forces use. The reader is meant to function the more-or-less passive repent of auctorial that means whereas any deviation from the meanings clearly marked forth among the text is viewed negatively, as failure to with success perceive what the author was attempting to mention.

This has coincided with Hicks later statements that "If film producer desires to create a gay superhero, they'll make a gay superhero." This argument seeks to put Marvel and its owner Disney fully to blame of the that means creating, but that is not how meaning is created around popular culture. The dominant heterosexual narratives in Captain America don't seem to be absolute and queer fans undermine this institutional power to form their own area among standard culture. Based on the explanation above, the researcher would like to investigate how Captain American Trilogy movie contain elements of querness in create Captain American as a hero.

In this reseach the theory about gender based on Judith Butler and Michel Foucault will be implemented. Definition of gender is distinguished from the understanding of one's sex which is a biological factor that is considered irreversible. The concept of gender can be seen in the activities of daily life in society which still impose segregation between the domestic domain as a feminine realm and an area of women and the public sphere as a masculine domain which is an area belonging to men. The gender concept is neutral and 
does not differentiate status between women and men. Menn can also become victims,so the concept of gender is more appropriate to be used to see inequalities in society due to the workings of an ideology.

Butler in his book Gender Trouble (1999) states that gender, which is a social construction, cannot be considered, there are only two because this view only represents heterosexual groups, whereas in the community there are also homosexual groups. Thus, according to him, gender is not universal, but plural. Gender meaning is not stable because gender concepts change from time to time and differ from place to place. Gender is always related to aspects such as race, class, ethnicity, sexuality and locality, so gender cannot be free from the politics and culture that produces it and maintains it.

Michel Foucault distinguishes sex from sexuality. For Foucault sexuality cannot be understood in a biological sense that leads to the reproduction of species. Foucault simply understands sexuality as a person using human's energy and human's pleasure to produce the truth. This separation was justified by Bob Francouer, a Professor at Fairleigh Dickinson University and editor of the International Encyclopedia on sexuality. He stated that :

"Sexuality and spirituality are always related and interwoven since the beginning of human civilization. Only in the last 2000 to 3000 years from the western civilizations. They are not only separated, even they are seen as contradicting one another. this contradiction comes from the dualism of Greek philosophy and the dichotomy of views of man as matter and spirit, the good and evil, men and women."

This power, according to Foucault, works in a capillary manner, starting from the most private domains where the main driving force of power is sexual drive. In Foucault's view, power is not merely linear and direct in that one party acts as an oppressor and the other acts as an oppressed. Because according to

Received April 07, 2019 ; Revised April 20, 2019 ; Accepted Mei 7, 2019 
Foucault, power is always accompanied by resistance so that power is never total. Power, repression, and resistance are always in a reciprocal relationship that pushes each other and encourages each other. The power network in the Foucault concept is a dynamic power relationship, with unlimited possibilities, and each individual in this power network has the opportunity to negotiate (Mills, 2003: 29).

\section{RESEARCH METHOD}

This study uses qualitative methods with a critical paradigm. Norman Denzim and Yvonna S. Lincoln (2009) said that research using critical discourse would be best understood in the context of empowering individuals. Research wishing to hold a critical degree must be associated with an attempt to oppose injustice in a particular society or confinement of power in society. The critical discourse method is to interpret the discourse to find out about the meaning, image and importance behind the discourse by taking into account actions, context, history, power and ideology. Horkeimer states clearly when he shows that critical theory and research are never satisfied if the results are only to increase knowledge ( Norman K. dan Lincoln. 2009: 174)

The method of critical discourse analysis is an analytical method that focuses on linguistic aspects and contexts related to that aspect. Discourse analysis does use language in the text to be analyzed, but it does not merely describe language aspects, but also relates to context. Context here means that language is used for certain purposes and practices, including the practice of power (Eriyanto, 2001: 7).

\section{RESULTS AND DISCUSSION}

While many people have donned the red, white, and blue costume over the years, the first and most common Captain America is Steve Rogers. Rogers 
had tried to enlist in the army to fight during World War II for several times, but was denied as a result of his weak physical condition. However, this does not stop the soon-to-be hero; he is given a chance to join a U.S. super-soldier program and is injected with a blood serum that produces him extraordinary work and intelligent. The character then goes on to fight within the war with consistent partner, United States President "Bucky" Barnes, United Nations agency in additional recent comics has taken on the alter-ego, the Winter Soldier.

Steve Rogers became Captain America through a combination of VitaRays and a dose of Dr. Erskine's Super Soldier Serum. Since that day, he's punched out Hitler, been a werewolf, traveled into space, died and been reborn, regressed into childhood and aged into the body of a powerless 95-year-old man. Stasis, crisis, resolution, month when month, for 75 years. The only constant in Steve's life is life-altering amendment. Coming out of the closet or discovering his feelings for the first time would be right up there with the kind of drastic changes he has dealt with for 75 years. Meanwhile it doesn't look like Marvel intends to portray Captain America as queer now or in the foreseeable future, that isn't to say we should dismiss that it could ever happen. Joe and Anthony Russo, the directors of Winter Soldier, Civil Warand the Infinity War, and End Gamec are on record saying the chances of a LGBQT character in the Marvel medium universe ar "strong." That most likely will not be Captain America, even with more of Marvel's audience demanding Captain America upgrade his red, white, and blue with some more rainbow hues. But the long run is wide hospitable experimentation and growth. Cap has had always embodied progressive, inclusive values, not just those currently tolerated or politically safe, that's who Captain is, a hero and a soldier.

Bucky Barnes, as he is most commonly referred too, was first introduced as a teenager at the end of Captain America part 1 where he discovers Steve 
Rogers changing into his Captain America costume and immediately becomes Rogers' partner. Together they take on many missions, but the partnership is brought to an end in the 1964 issue Avengers part 4 when Captain America and Bucky try to stop an exploding plane. Bucky was killed and Captain America was thrown into the ocean where he froze and remained there for several years, until he was discovered by the Avengers.

In the modern Marvel Cinematic Universe Bucky still dies (only to return again) and Captain America still gets frozen. However, this story sets up Steve and Bucky as friends who have grown up together looking out for and protecting each other like two brothers. After Bucky's probable death, Captain America sacrifices himself to save Americans by crashing a bomber into the Arctic freezing himself and the bombs. When the next installment of Captain America film, The Winter Soldier, catches up with the characters 75 years later, these heroes have split apart. Bucky is now a brainwashed Russian assassin and Captain America is a sad newly defrosted and out-of-place superhero or soldier, but both, according to some queer fans, are still very much in love. The first thing we noticed there was queerbaiting between the two of them was when thet talked to eachother. Bucky "don't do anything stupid untill i get back" then Steve says "how can i? You're taking all the stupid with you" Bucky comes back to Steve only to hug him and saying “you punk!" Steve replies “jerk!" (00:14:20, Captain America : The First Avenger (CATFA)), they hug intensely like a couple of lovers. From this we can see that they care about each other more than just best friend.

The foundation of Captain America's queer reading is that this relationship with Bucky Barnes. As Robert G. Weiner (1994) writes in "Sixty 5 Years of Guilt Over the Death of Bucky" this relationship could be a permanent side of the comic. This piece also highlights the inherently sad story of reading Captain America as a love story and not brotherly love, but it also is part of why the story is so successful and popular. When Captain America is woke up from 
physiological state by the Avengers, His first words are "Bucky - Bucky! Look Out!" Lee In following comics Steve Rogers "tortured himself by staring at recent photos of himself and Bucky" and one character comments on his lamentation over the death of " his partner". In Captain America The First Avenger (CATFA) after Steve rescuing Bucky from the Hydra's basecamp they are trapped in a burning building, they had to escape from that building otherwise they will get killed, Bucky made it to the other floor by jumping high from the bridge while Steve is stuck in the bridge, Bucky couldn't help to lose him in this battle, but Steve insists him to leave without him but Bucky refuses it by saying "No! not without you!" (01::08:28, CATFA). This can be read simply as survivor's guilt, but the relationship can suggest that Cap is romantically in love with his partner Bucky and it is this close relationship that is the basis of queer readings surrounding Captain America and this scene does not only show their queerness but it also shows their patriotism as queer soldiers. Steve saved the entire howling commandos that were kidnapped by Hydra. Since then Steve received medal for valour for his patriot act.

Steve is someone who has a very calm personality but when Hydra made Bucky fall from the train, he got really upset and angry 'i'm going for Schimdt, i'm not gonna stop untill the wole Hydra dead or captured" (01:30:25, CATFA) this is the same Steve who used to be very skinny and calm but when it comes to Bucky he's completely different person he would do anything for Bucky. Both Bucky and Steve have a very strong bond towards each other they even say the sacred words that only the two of them know what it means. In the Captain America: The Winter Soldier (CATWS) the second installment of this trilogy Bucky says to Steve "i'm with you till the end of the line, pal" (01:33:14, CATWS) this shows that their queerness is significant as they really care about each other more than just best friend. Bucky goes on a mission to kill Captain America, he is a brainwashed assassin so he doesn't know that Captain America is Steve Roger his childhood 
friend, the leader of new Hydra is interrogating him but the only thing he remmebers is the man in the bridge he's supposed to kill to finish his mission. "the man on the bridge...who is he?" (01:28:35, CATWS). The way Bucky recalls his friend indicates romantic feeling he has for Steve. Even after Bucky punches him in the face over and over Steve still believes that his best friend still remember him, Steve "you're my friend" then Bucky replies "you're my mission!" (01:59:20, CATWS) Bucky keeps punching him and the suddenly stops as Steve says "then finish it, cause i'm with you till the of the line" Bucky is lost in thought as they both are staring each other eyes to eyes, they are in nostalgic moment and clearly in love.

These queer reading can be found in many places, especially the popular fan fiction collaborative site Archive of Our Own. On this website many thousands of individuals produce and share their own stories, or fanfics, that feature common culture characters. Of the over 100 thousand fanfics dedicated to Marvel, the foremost common of any relationship gay or straight is between Captain America and Bucky Barnes with over fourty thousand writing them as couple of lovers (Archive of Our Own Beta "Works in Marvel”, 2016). One such fanfic, Keepsake by a user named Sunset2304 describes Steve Rogers reminiscing about his romantic relationship with Bucky to fellow Avenger, Natasha Romanov. When talking regarding the time once he saved Bucky's life within the army he says, "He stayed by my aspect afterward, stopped drinking, slept in my tent and kissed Pine Tree State goodnight each time before he closed his eyes. Other people knew however no one questioned it, similar to I ne'er did. I favourite him from the primary to the last second Nat." This quote highlights a selected army narrative, particularly that individuals knew they were gay, but didn't care. This is a awfully specific condition that arose attributable to socio-historic forces close warfare II. As D'Emilio (1983) discusses within the second chapter of Sexual Politics, Sexual Communities, warfare II ends up in less social and actual policing 
Of queer individual, for, in the grand theme of things, the war was the greater "threat". According to D'Emilio, this including the creation of a lot of heavily inhabited same-sex environments, functioned as "a nationwide starting up experience" . This expertise is deeply tied to the stories that area unit told regarding Bucky and Cap. This queer history is superimposed into the character and helps spur a queer reading. Foucault says at now there was a political, economic and technical excitement to speak regarding sex. Sex became a call for management procedures. It became a policing matter.

"If sex is repressed, that is, condemned to prohibition, nonexistence, and silence, then the mere fact that one is speaking about it has the appearance of a deliberate transgression. A person who holds forth in such language places himself to a certain extent outside the reach of power; he upsets established law; he somehow anticipates the coming freedom."

- Michel Foucault, The History of Sexuality - Volume I (p. 6: 1990)

Though the thousands of fanfics vary greatly, for instance, some place the couple in domestic things and have Steve defend Bucky's brainwashed actions because the Winter Solider in court, each of these reflect a unique queer identity. As Gans (1999) said, "Popular culture has vie a helpful role within the method of facultative normal individuals to become people, develop their identities, and notice ways in which of achieving creativeness and expressive style."(p. 70) The act of making and sustaining a queer reading of Captain America helps kind and validate those identities with many various forms of queer identities being drawn in these fancies.

All these fan fictions become a part of popular culture and Captain America; as Grind staff states, "popular culture is not an object or text itself, but "something constituted both through the act of consumption and thru the act of theoretical engagement." Structuring a queer Captain America story that moves 
Through nearly 50 years of significant U.S. history is associate degree act of inculcation oddity into the landscape of America's past. By light and discussing Captain America's oddity in relevancy the queer men within the defense force throughout War World II and larger history, queer readers ask for to affirm their place in America's past, that successively validates their place within the gift.

This historical compendium of a bisexual Captain America is also a theoretical engagement with the text; but, several would argue that the approach queer readers have interaction with Captain America as popular culture is wrong. The most recent Captain America film, Captain America: war, which may be roughly delineated as film regarding Cap fighting the govt and breaking apart the Avengers team in order to safeguard Bucky, is a particularly enticing plot for queer readings. However, the film takes action to deter viewers from branching from the dominant straight narrative. Disney and Marvel, in an effort to avoid queer readings in the third installment of Captain America : Civil War, created an underdeveloped heterosexual sub-plot where Steve kisses Sharon Carter, the niece of Peggy Carter (Yes, this is the same Peggy Carter that Steve Rogers has had a relationship with in past Marvel films, so it's weird). Understandably several queer reading folks, such as Vanity Fair's Joanna Robinson, were upset by this. In her article is that this the One Flaw within the Otherwise nice Captain America:Civil War? She discusses her issues with the kiss. She highlights directors Joe and Anthony Russo's practice of queer baiting, which the practice of creators is validating a queer reading in public, but never actually giving audiences an explicitly queer character within the cultural item they manufacture. Joe Russo whereas discussing Cap and Bucky in China aforesaid,

[...] it's great to see people argue about it what that relationship means to them. We will never define it as filmmakers, explicitly, but however people want to interpret it they can interpret it.(Robinson). 
These sounds like a fine statement, however Robinson argues it's a transparent lie. The heterosexual kiss in warfare plus dialogue between Bucky and Cap concerning chasing gals within the 40's is expressly stating that Captain America is straight. This has revealed a nuanced relationship between cultural creator and their audience, specifically queer readers. Russo desires to encourage as many folks to visualize the film as attainable, thus during this case by pandering to queer readers he's supporting his career. However, once it comes time to really create the film, heteronormative attitudes dominate the screen. However, this will highlight Russo's suggestion that fans have the power associated authority to make their own which means (not that the community required his approval) around an expertise and as Lynn (2008) said "coauthor" the film (114).

However, this doesn't mean that Marvel, Russo, or perhaps most fans support this "co-authored" queer reading. Because of the linkage of physiological property to truth, physiological property developed into a marker of identity. In different words,

the observe of physiological property became bound to truth, therefore turning into associate metaphysics categorization no completely different from racial or ethnic typologies. In order to proof this notion, physicist eludes the invention of the construct of sexual activity (and in tandem bicycle, the invention of the homosexual), contestation once more that sexual activity was not discovered, but rather, produced through dialectical exchange.

\section{CONCLUSION}

The struggle queer individuals endure with hetero normative standard culture forces Captain America Figure and his close friend change standard culture things and forms to create them applicable. While the power bloc will continue to dominate Captain America has cannoned with hetero normative 
narratives, Captain America is still a perfect form to subvert. His shut relationship with Bucky provides for a queer reading and therefore the history of Captain America among the relative queer freedom caused by socio-historic conditions of war II find this queer reading during a larger queer history. And by claiming Steve Rogers and Bucky as their own queer peoplecreate space to express their identities and reaffirm the place of heroic queer people in American history which, as the descendants of that patriotic past, merits them a place within that history and within modern American society.

Cap and Bucky obtaining along within the films may create a lot of sense. In comic series, Bucky was a plucky kid who idolized Captain America before becoming his partner and eventually dying on a mission with him. The age distinction was stressed, with Bucky being known as Cap's teenage sidekick. That side of his character was integral to their father-son relationship. A relationship between the 2 within the books could be a tricky sell even supposing Bucky is currently Cap's age (thanks to the wonders of Cryo sleep) as a result of there ar still the politics of power, authority, and grooming in their early relationship to think about. Meanwhile, the moving-picture show versions of Cap and Bucky don't have that downside. The medium Bucky swaps out him as a immature crony and instead replaces it wholesale with the origin of Arnie Philip Roth. In the movies, Bucky is Steve's childhood ally, the bigger, stronger of the two who protects him from bullies and whose family is a second home to Steve.

\section{REFERENCES}

Barraclough, Leo. (2016). “Rupert Murdoch's News Corp. Sets Up Conservative Website Heat Street." Variety, 17 Feb. 2016.

http://variety.com/ 2016/digital/global/news-corp-conservative-website-heat street-120170810, Visites on 19 May 2019. 
Butler, J. (1999). Gender trouble. New York and London: Routledge.

Denzin, Norman K. dan Yvonna S. Lincoln. (2009). Handbook of Qualitative Reserch. Yogyakarta: Pustaka Pelajar

D’Emilio, J. (1983.) Forging a Group Identity: World War II and the Emergence ofan Urban Gay Subculture." Sexual Politics, Sexual Communities, First ed. Chicago: Chicago Print.

Eriyanto. (2001). Analisis Wacana: Pengantar Analisis Teks Media. Yogyakarta: LKIS

Foucault,Michel.(1990) The History of Sexuality - Volume I: An Introduction. Trans. Robert Hurley. New York: Vintage Books.

Foucault, Michel (1990). The History of Sexuality - Volume II: The Use of leasure. Trans. Robert Hurley. New York: Vintage Books.

Foucault, Michel. (1990) The History of Sexuality: An Introduction. NY: Vintage. Foucault, Michel. (1982) An Introduction to the Study of His Thought. The Edwin Melen Press: New York and Toronto, Page 125.

Gans, Herbert J. (1999). Popular Culture and High Culture: An Analysis and

Evaluation of Taste. New York: Basic.

Grindstaff,.L.(2001). Popular Culture: A Definition," in Encyclopedia of

Contemporary American Culture, ed. by Gary McDonogh, Robert Gregg, and Cindy

Wong. New York: Routledge.

Hicks, Will. (2016). "Captain America Is Straight and Libertarian-Deal with It. " Heat Street. Heat Street, 10 May 2016. Visited on 19 May 2019.

<https://heatst.com/culture-wars/captain-america-is-straight-and-libertarian- dealwith-it/>.

Jefferson. (2009). Captain America and the Struggle of the Superhero: Critical Essays. NC: McFarland.

Lynne, Connor. (2008). In and Out of the Dark: A Theory of Audience Behavior from 
Sophocles to Spoken Word." Engaging Art: The next Great Transformation of America's Cultural Life. New York: Routledge.

Mills, S. (2007) Diskursus: Sebuah Piranti Analisis dalam Kajian Ilmu Sosial (terj.). Jakarta: Qalam.

Mojo. (2016)."Captain America: Civil War (2016)—Box Office Mojo.”

http://www.boxofficemojo.com/movies/?id=marvel2016.htm, visited on 16 May 2019.

Dropdeaddream, and WhatAreFears. "Archive of Our Own Beta." Show Chapter | Archive of Our Own. Archive of Our Own, 17 June 2014. Web. 18 May 2016. <http://archiveofourown.org/works/1799623/chapters/3859159>. 